\title{
A systems-biology approach to understanding the ciliopathy disorders
}

\author{
Ji Eun Lee and Joseph G Gleeson*
}

\begin{abstract}
'Ciliopathies' are an emerging class of genetic multisystemic human disorders that are caused by a multitude of largely unrelated genes that affect ciliary structure/function. They are unified by shared clinical features, such as mental retardation, cystic kidney, retinal defects and polydactyly, and by the common localization of the protein products of these genes at or near the primary cilium of cells. With the realization that many previously disparate conditions are a part of this spectrum of disorders, there has been tremendous interest in the function of cilia in developmental signaling and homeostasis. Ciliopathies are mostly inherited as simple recessive traits, but phenotypic expressivity is under the control of numerous genetic modifiers, putting these conditions at the interface of simple and complex genetics. In this review, we discuss the ever-expanding ciliopathy field, which has three interrelated goals: developing a comprehensive understanding of genes mutated in the ciliopathies and required for ciliogenesis; understanding how the encoded proteins work together in complexes and networks to modulate activity and structure-function relationships; and uncovering signaling pathways and modifier relationships.
\end{abstract}

\section{Ciliary biology}

Motile cilia (flagella) arose in the eukaryotic lineage in single-celled protists, where they took on signaling capacities, and it was only with the emergence of the multicellular animal kingdom that their non-motile cousins (primary cilia) appeared. Motile cilia in multi-ciliated organisms beat in coordinated waves and are found in various tissues, where they perform a variety of functions. For example, motile cilia in the trachea function in

*Correspondence: jogleeson@ucsd.edu

Neurogenetics Laboratory, Howard Hughes Medical Institute, Department of Neuroscience and Pediatrics, University of California, San Diego 92093-0691, USA sweeping mucus and particulates out of the lungs and in the fallopian tubes they assist in moving the ovum from the fallopian tube to the uterus. Primary cilia, on the other hand, have a role in sensory detection. In worms, for example, they are present exclusively in a handful of neurons used to detect food. Although there are some cells with motile and primary cilia in vertebrates, most cells have primary cilia whereas only a handful of cells have motile cilia. Both types of cilia have a protruding microtubule structure called the axoneme emerging from a basal body that contains the pair of centrioles (Figure 1). Structurally, the axonemes in both motile and primary cilia comprise nine doublet microtubules, but primary cilia differ in that they lack the two central microtubules $(9+0)$ that motile cilia have $(9+2)$.

Cilia maintain separate cytoplasmic and membrane compartments, but are completely lacking vesicles. Instead cilia rely on specialized modes of transportation called intraflagellar transport (IFT) to deliver cargo proteins and lipids along the axoneme. IFT can operate in the anterograde direction (towards the ciliary tip) using complex B factors, or in the retrograde direction (towards the ciliary base) using complex A factors; together these factors regulate the transport speed and net cargo flux. An important, recently emerged aspect of cilia is the gatekeeper role of the septin family of proteins, regulating initial entry and exit of ciliary factors at the base of the cilium [1]. The transition zone, where the gatekeeper functions, is an adjacent structure at the base of the cilium, forming the linkers between microtubule and ciliary membrane; it is probably required for unloading ciliarydirected cargo and sorting ciliary-based signaling mechanisms [2] so that the cell can interpret their context.

\section{Emerging genetics of the ciliopathies}

Although ciliopathies are individually rare disorders, an amazing spectrum of what were previously disparate syndromes is now recognized as part of the ciliopathy spectrum. Ciliopathies can be subdivided into 'motile ciliopathies' and 'non-motile ciliopathies', although we usually define ciliopathies as disorders that result from aplasia and/or disrupted function of primary cilia. Motile ciliopathies comprise a class of disorders displaying 
(a)

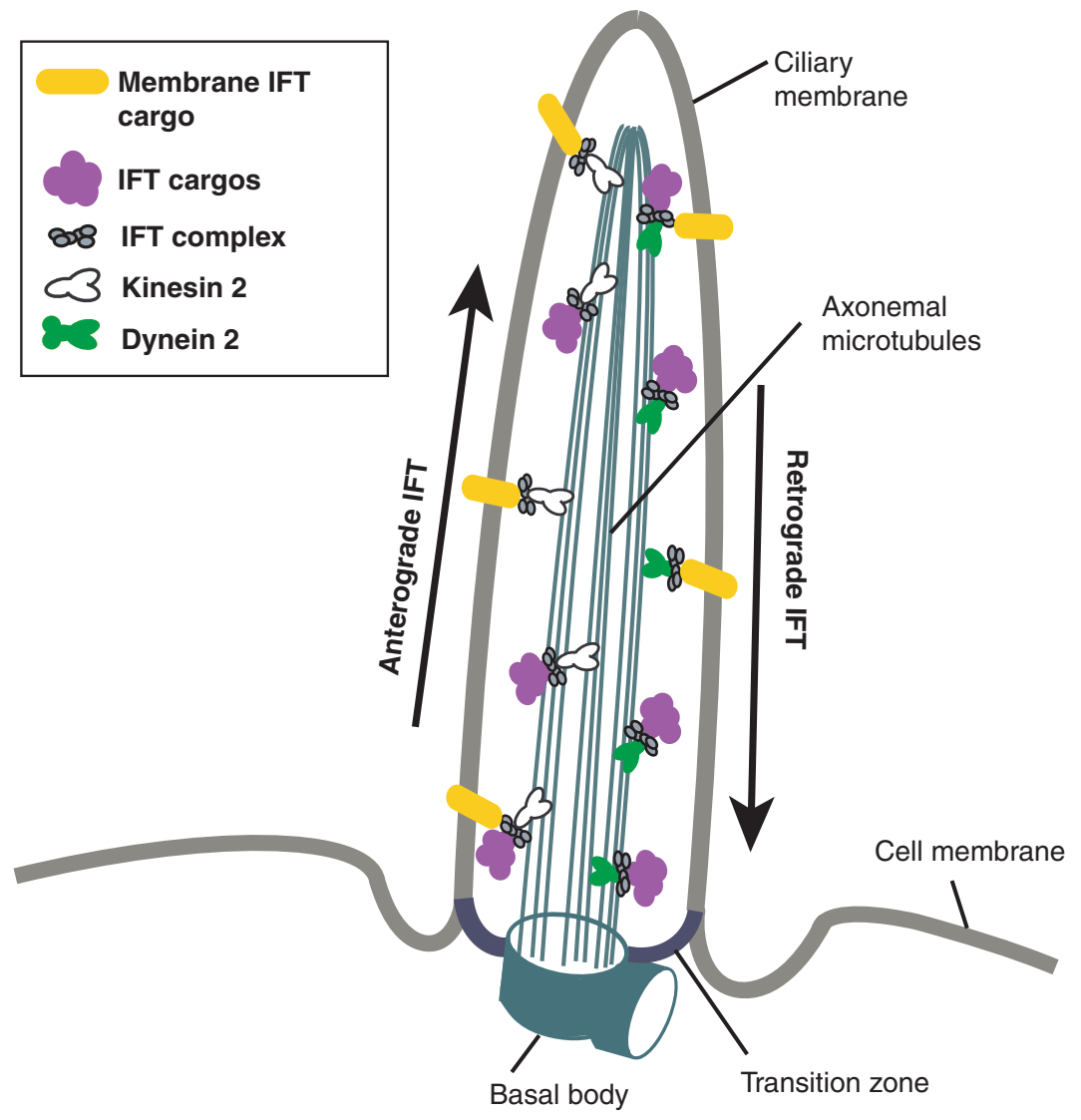

(b)

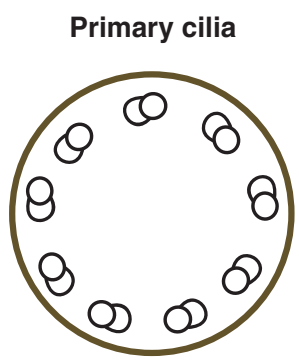

$9+0$

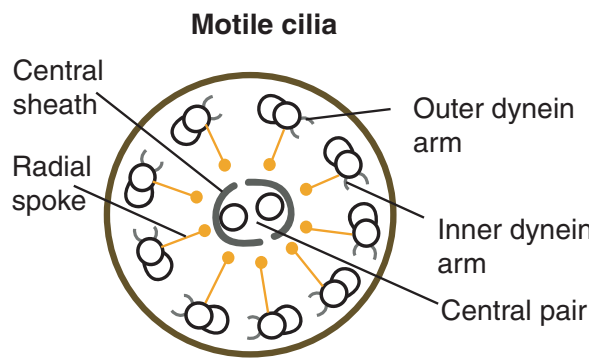

$9+2$

Figure 1. Schematic of a primary (non-motile) cilium and intraflagellar transport (IFT). (a) Ciliary cargo proteins, transported from the Golgi network to the basal body, move between the base and the tip of the cilium by IFT. Motor proteins, such as kinesin 2 and dynein 2, associated with IFT complexes, are responsible for movement along axonemal microtubules in an anterograde and retrograde direction, respectively. (b) Schematic diagram of axoneme cross-section. Motile cilia have a $9+2$ microtubule pair ultrastructure, with inner and outer dynein arms, whereas primary cilia typically have $9+0$ arrangement, without dynein arms.

prominent situs inversus (a condition in which the normal positions of organs are reversed). Non-motile ciliopathies show prominent but mixed features in several vital organs, including the brain, kidney and liver, and others, such as the eye and digit. Ciliopathies range from largely organ-specific disorders, such as polycystic kidney disease (PKD), to pleiotropic disorders, such as cerebello-oculo-renal syndrome (CORS), Bardet-Biedl syndrome (BBS), Jeune asphyxiating thoracic dystrophy (JATD) and Meckel-Gruber syndrome (MKS) (Figure 2). All ciliopathies known so far show a recessive mode of inheritance, either autosomal or X-linked, with strong evidence of genetic modifiers that determine expressivity. Moreover, clinically distinguishable ciliopathies often result from mutations in a single gene (Table 1 ), suggesting complex genetic networks. 


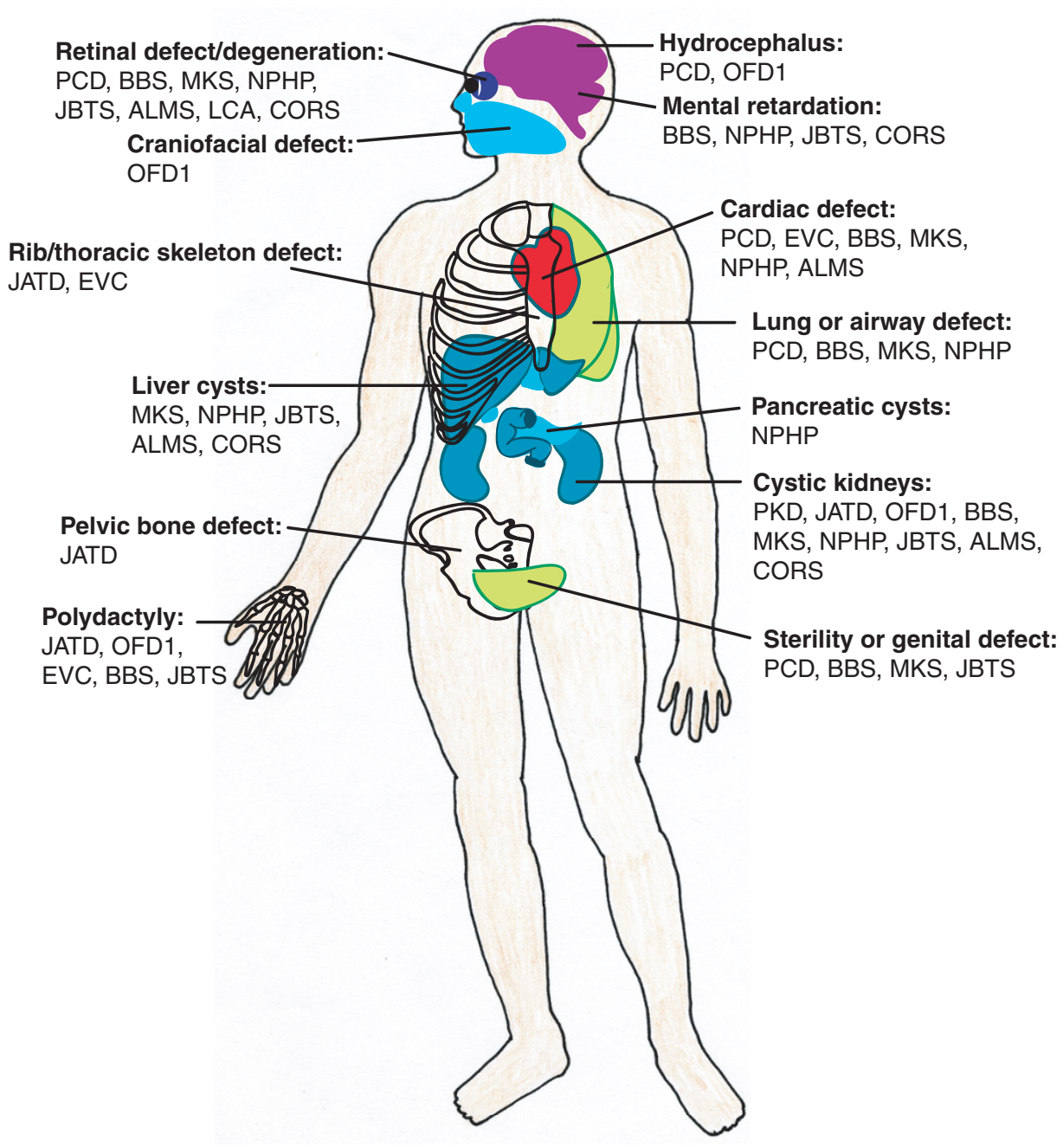

Figure 2. Almost every organ in the body shows vulnerability in the ciliopathies. Most ciliopathies have overlapping clinical features in multiple organs. Cystic kidney and retinal defects are frequently observed. Skeletal dysplasia is predominantly seen in JATD, OFD1 and EVC. ALMS, Alström syndrome; BBS, Bardet-Biedl syndrome; CORS, cerebello-oculo-renal syndrome; EVC, Ellis-van Creveld syndrome; JATD, Jeune asphyxiating thoracic dystrophy; JBTS, Joubert syndrome; LCA, Leber congenital amaurosis; MKS, Meckel syndrome; NPHP, nephronophthisis; OFD1, oral-facialdigital syndrome type 1; PCD, primary ciliary dyskinesia; PKD, polycystic kidney disease.

Although the disease-specific function of any single mutated gene in a particular ciliopathy has not yet been understood, the identification of several causative genes has contributed to a better understanding of the pathogenesis of the disorders and the biological functions of cilia over the past two decades. In the attempt to identify candidate genes, diverse high-throughput techniques have been applied, such as in silico comparative genomics, transcriptome analysis including analysis of X-box promoters, which are involved in the regulation of ciliary genes in Caenorhabditis elegans, and proteomics. These complementary approaches led to the identification of several new disease-causative ciliary genes and also propelled the ciliary biology field from basic science into the biomedical realm.
Here, we summarize the clinical and genetic features of each ciliopathy disorder and outline the expanding range of a systems-biology approach applied to the study of ciliopathies. We also discuss advantages of the new genomic approaches and future strategies that will assist the transfer of research achievements into clinical practice.

\section{Genes required for ciliary-mediated signaling and ciliary function}

What are the roles of primary cilia and how were these roles missed for so long? The primary cilia that were evident from detailed electron microscopic studies over 40 years ago were initially considered to be evolutionary remnants without specific function. The first few genes identified from positional cloning of human and mouse 
Table 1. Ciliopathies, genes and subcellular functions of the proteins

\begin{tabular}{|c|c|c|c|c|}
\hline Disorders & Symptoms & Inheritance & Causative genes & Putative protein functions \\
\hline $\begin{array}{l}\text { Primary ciliary } \\
\text { dyskinesia (PCD)/ } \\
\text { Kartagener } \\
\text { syndrome (KS) }\end{array}$ & $\begin{array}{l}\text { Chronic sinusitis, } \\
\text { bronchiectasis and infertility } \\
\text { with situs inversus (KS } \\
\text { only) and occasional } \\
\text { hydrocephalus (PCD) }\end{array}$ & $\begin{array}{l}\text { Autosomal } \\
\text { recessive }\end{array}$ & $\begin{array}{l}\text { DNAH5 } \\
\text { DNAH11 } \\
\text { DNAl1 } \\
\text { DNAl2 } \\
\text { TXNDC3 } \\
\text { KTU } \\
\text { RSPH9 } \\
\text { RSPH4A } \\
\text { LRRC50 }\end{array}$ & $\begin{array}{l}\text { Cilia motility } \\
\text { Cilia motility } \\
\text { Cilia motility } \\
\text { Cilia motility } \\
\text { Unknown } \\
\text { Dynein arm preassembly, Cilia motility } \\
\text { Central pair/motility } \\
\text { Central pair/motility } \\
\text { Cilia motility }\end{array}$ \\
\hline $\begin{array}{l}\text { Leber congenital } \\
\text { amaurosis (LCA) }\end{array}$ & $\begin{array}{l}\text { Retinal dystrophy, blindness } \\
\text { or severe visual impairment } \\
\text { such as sensory nystagmus, } \\
\text { amaurotic pupils and } \\
\text { absent electroretinogram } \\
\text { signal }\end{array}$ & $\begin{array}{l}\text { Autosomal } \\
\text { recessive }\end{array}$ & $\begin{array}{l}\text { CEP290;NPHP6* } \\
\text { LCA5 } \\
\text { TULP1 } \\
\text { RPGRIP1 }\end{array}$ & $\begin{array}{l}\text { RPGR complex, trafficking } \\
\text { RPGR complex, trafficking } \\
\text { Rhodopsin trafficking } \\
\text { RPGR complex }\end{array}$ \\
\hline $\begin{array}{l}\text { Polycystic kidney } \\
\text { disease (PKD): } \\
\text { dominant (ADPKD), } \\
\text { recessive (ARPKD) }\end{array}$ & $\begin{array}{l}\text { Hepatic cysts, pancreatic } \\
\text { cysts (10\%), cysts in the } \\
\text { nephron (ADPKD only) and } \\
\text { hepatic fibrosis, cysts in } \\
\text { collecting ducts (ARPKD } \\
\text { only) }\end{array}$ & $\begin{array}{l}\text { Autosomal } \\
\text { dominant, } \\
\text { Autosomal } \\
\text { recessive }\end{array}$ & $\begin{array}{l}\text { PKD1 } \\
\text { PKD2 } \\
\text { PKHD1 }\end{array}$ & $\begin{array}{l}\text { Mechanosensation, cell-cell or cell-matrix interactions } \\
\text { Probable calcium channel protein } \\
\text { Probable receptor protein, PC2 modulation }\end{array}$ \\
\hline $\begin{array}{l}\text { Jeune asphyxiating } \\
\text { thoracic dystrophy } \\
\text { (JATD) }\end{array}$ & $\begin{array}{l}\text { Postaxial polydactyly, short } \\
\text { limbs, short and slender } \\
\text { ribs, small ilia, irregular } \\
\text { acetabulum and cystic } \\
\text { kidney }\end{array}$ & $\begin{array}{l}\text { Autosomal } \\
\text { recessive }\end{array}$ & ATD1 & Role in Shh signaling \\
\hline $\begin{array}{l}\text { Ellis-van Creveld } \\
\text { syndrome (EVC) }\end{array}$ & $\begin{array}{l}\text { Polydactyly, short ribs, } \\
\text { dysplastic fingernails/teeth } \\
\text { and cardiac defects }\end{array}$ & $\begin{array}{l}\text { Autosomal } \\
\text { recessive }\end{array}$ & $\begin{array}{l}\text { EVC1 } \\
\text { EVC2 }\end{array}$ & $\begin{array}{l}\text { Unknown } \\
\text { Unknown }\end{array}$ \\
\hline $\begin{array}{l}\text { Oral-facial-digital } \\
\text { syndrome type I } \\
\text { (OFD1) }\end{array}$ & $\begin{array}{l}\text { Craniofacial malformations, } \\
\text { postaxial polydactyly, } \\
\text { central nervous system } \\
\text { defects and cystic kidney } \\
(\sim 15 \%)\end{array}$ & $\begin{array}{l}\text { X-linked } \\
\text { dominant }\end{array}$ & OFD $1^{*}$ & $\begin{array}{l}\text { Ciliogenesis, Wnt/PCP signaling, association with LCA5 and } \\
\text { SDCCAG8 }\end{array}$ \\
\hline $\begin{array}{l}\text { Nephronophthisis } \\
\text { (NPHP) }\end{array}$ & $\begin{array}{l}\text { Triad of tubular basement } \\
\text { membrane disruption, } \\
\text { tubulointerstitial } \\
\text { nephropathy, } \\
\text { corticomedullary cysts. } \\
\text { Pancreatic/hepatic fibrosis, } \\
\text { situs inversus, retinitis } \\
\text { pigmentosa, cerebellar } \\
\text { vermis hypoplasia, } \\
\text { oculomotor apraxia and } \\
\text { mental retardation }(\sim 10 \%)\end{array}$ & $\begin{array}{l}\text { Autosomal } \\
\text { recessive }\end{array}$ & $\begin{array}{l}\text { NPHP1 * } \\
\text { NPHP2;INVS } \\
\text { NPHP3 } \\
\text { NPHP4 } \\
\text { NPHP5;IQCB1 } \\
\text { NPHP6;CEP290* } \\
\text { NPHP7;CLIS2 } \\
\text { NPHP8;RPGRIP1L* } \\
\text { NPHP9;NEK8 } \\
\text { NPHP10;SDCCAG8 } \\
\text { NPHP11;TMEM67* } \\
\text { NPHPL1;XPNPEP3 }\end{array}$ & $\begin{array}{l}\text { Cilia structure, cell-cell adhesion } \\
\text { Wnt/PCP, cell cycle control } \\
\text { Wnt/PCP pathway } \\
\text { Cilia structure, IFT } \\
\text { RPGR/Calmodulin complex } \\
\text { RPGR complex, trafficking } \\
\text { Transcription factor, Wnt } \\
\text { Shh signaling } \\
\text { Modulation of PC1 and PC2 } \\
\text { Association with OFD1 } \\
\text { Ciliogenesis } \\
\text { Unknown }\end{array}$ \\
\hline $\begin{array}{l}\text { Joubert syndrome } \\
\text { (JBTS)/JBTS-related } \\
\text { disorder (JSRD) }\end{array}$ & $\begin{array}{l}\text { Hypotonia, ataxia, } \\
\text { psychomotor delay, } \\
\text { oculomotor apraxia, } \\
\text { retinal degeneration } \\
\text { and mental retardation. } \\
\text { Occipital encephalocele, } \\
\text { polymicrogyria, cystic } \\
\text { kidney, hepatic fibrosis and } \\
\text { polydactyly (JSRD) }\end{array}$ & $\begin{array}{l}\text { Autosomal } \\
\text { recessive }\end{array}$ & $\begin{array}{l}\text { JBTS1;INPP5E } \\
\text { JBTS2;TMEM216* } \\
\text { JBTS3;AHI1 } \\
\text { JBTS4;NPHP1* } \\
\text { JBTS5;CEP290* } \\
\text { JBTS6;TMEM67* } \\
\text { JBTS7;RPGRIP1L* } \\
\text { JBTS8;ARL13B } \\
\text { JBTS9;CC2D2A* } \\
\text { JBTS10;OFD1* } \\
\text { JBTS11;TTC21B } \\
\text { JBTS12;KIF7 } \\
\text { JBTS13;TCTN1 }\end{array}$ & $\begin{array}{l}\text { Cilia stability, phosphatidylinositol signaling } \\
\text { Ciliogenesis, centrosomal docking, PCP signaling } \\
\text { Wnt signaling } \\
\text { Cilia structure, cell-cell adhesion } \\
\text { RPGR complex, trafficking } \\
\text { Ciliogenesis } \\
\text { Shh signaling } \\
\text { Cilia structure, IFT } \\
\text { Association with CEP290 } \\
\text { Ciliogenesis, Wnt/PCP, association with LCA5 and SDCCAG8 } \\
\text { Ciliogenesis } \\
\text { Shh signaling, microtubule dynamics } \\
\text { Transition zone complex regulation }\end{array}$ \\
\hline
\end{tabular}


Table 1. Ciliopathies, genes and subcellular functions of the proteins

\begin{tabular}{|c|c|c|c|c|}
\hline Disorders & Symptoms & Inheritance & Causative genes & Putative protein functions \\
\hline \multirow{12}{*}{$\begin{array}{l}\text { Bardet-Biedl } \\
\text { syndrome (BBS) }\end{array}$} & \multirow{12}{*}{$\begin{array}{l}\text { Obesity, diabetes, } \\
\text { polydactyly, mental } \\
\text { retardation, cystic kidney, } \\
\text { retinitis pigmentosa, } \\
\text { hypogenitalism and situs } \\
\text { inversus }\end{array}$} & \multirow{12}{*}{$\begin{array}{l}\text { Autosomal } \\
\text { recessive }\end{array}$} & BBS1 & BBSome, Wnt/PCP, IFT/trafficking \\
\hline & & & BBS2 & BBSome, IFT/trafficking \\
\hline & & & $B B S 3 ; A R L 6$ & Vesicle trafficking \\
\hline & & & BBS4 & $\begin{array}{l}\text { BBSome, IFT/trafficking, microtubule anchoring, cell cycle } \\
\text { control }\end{array}$ \\
\hline & & & BBS5 & BBSome, IFT/trafficking, ciliogenesis \\
\hline & & & BBS6;MKKS & IFT/trafficking, Wnt/PCP, cytokinesis, chaperonin \\
\hline & & & BBS7 & BBSome, IFT/trafficking \\
\hline & & & BBS8;TTC8 & BBSome, IFT/trafficking \\
\hline & & & BBS9;PTHB1 & BBSome \\
\hline & & & BBS10 & Ciliogenesis, Wnt, chaperonin \\
\hline & & & BBS11;TRIM32 & E3 ubiquitin-protein ligase \\
\hline & & & BBS12 & Ciliogenesis, Wnt, chaperonin \\
\hline $\begin{array}{l}\text { Alström syndrome } \\
\text { (ALMS) }\end{array}$ & $\begin{array}{l}\text { Cone-rod retinal } \\
\text { dystrophy, hearing defects, } \\
\text { cardiomyopathy, early- } \\
\text { onset obesity, renal failure } \\
\text { and hepatic dysfunction }\end{array}$ & $\begin{array}{l}\text { Autosomal } \\
\text { recessive }\end{array}$ & ALMSI & Cilia maintenance \\
\hline \multirow{6}{*}{$\begin{array}{l}\text { Meckel-Gruber } \\
\text { syndrome (MKS) }\end{array}$} & \multirow{6}{*}{$\begin{array}{l}\text { Renal cysts, hepatic fibrosis, } \\
\text { central nervous system } \\
\text { malformations, polydactyly, } \\
\text { liver malformations, } \\
\text { laterality defects, cardiac } \\
\text { defects }\end{array}$} & \multirow{6}{*}{$\begin{array}{l}\text { Autosomal } \\
\text { recessive }\end{array}$} & MKSI & Ciliogenesis \\
\hline & & & MKS2;TMEM216* & Ciliogenesis, centrosomal docking, PCP signaling \\
\hline & & & MKS3;TMEM67* & Ciliogenesis \\
\hline & & & MKS4;CEP290* & RPGR complex, trafficking \\
\hline & & & MKS5;RPGRIPIL* & Shh signaling \\
\hline & & & MKS6;CC2D2A* & Association with CEP290 \\
\hline
\end{tabular}

Disorders are described in the order of increasing phenotypic severity. Asterisks indicate genes causing allelic disorders. Semicolons indicate two different names of the same gene. RPGR, retinitis pigmentosa GTPase regulator.

disease genes did not point to the cilium as the site of their action. It was not until the accumulation of evidence suggesting the localization of the encoded proteins at or near the cilium that the importance of the primary cilium was realized, and the field of ciliopathies was born [3-5]. The simplistic idea that these genes were required merely for assembly of a cilium was rapidly usurped by observations of defective signaling in specific pathways at the cilium, most notably the Sonic hedgehog (Shh), canonical and non-canonical Wnt, and platelet derived growth factor (PDGF) pathways (Figure 3 ). There are probably a wealth of other yet unexplored pathways that are modulated by the primary cilium, which cells seem to use to concentrate signals or to help convey the spatial and temporal context in which to interpret extracellular signals.

\section{Genes required for ciliary structure or motility}

Formation of ciliary axonemal structures, such as the dynein arms, radial spokes, central pair of microtubules and central sheath, is necessary for regulating motility and beating of the cilia (Figure 1). Patients with primary ciliary dyskinesia or Kartagener syndrome (PCD/KS) can show ultrastructural axonemal defects in motile cilia [6]. In addition, it is not surprising that many genes, such as DNAH5, DNAI1, DNAI2, DNAH1, KTU, RSPH9, RSPH4A and LRRC50, encoding proteins associated with ciliary axonemal architecture or entry of these factors into cilia, have been found to be mutated in PCD/KS [7-11].

Interestingly, a few genes mutated in the non-motile ciliopathies also seem to be linked with structural formation of the axoneme. For example, mutations of $A R L 13 B$ in mouse Joubert syndrome (JBTS) and NPHP4 in C. elegans nephronophthisis (NPHP) give rise to ultrastructural defects of the ciliary axoneme, although the defects are relatively subtle [12,13]. Patients with BBS have defects in the axoneme of spermatozoon flagella, which are closely related to cilia, and correspondingly Bbs2 knockout mice have abnormal spermatozoon flagellum formation [14]. The connection between ciliary structure and function remains a central focus of the field.

\section{Advanced high-throughput strategies in the study of ciliopathies}

Using traditional approaches of human genetics, such as positional cloning, meiotic mapping, physical mapping and candidate-gene sequencing [15], PKD1 in PKD [16] and NPHP1 in NPHP [17] were identified as initial causative genes of ciliopathies in the late 1990s. Further diverse approaches, including promoter analysis, comparative genomics, transcriptome analysis and proteomics, have resulted in the identification of numerous ciliary-related 
(a)

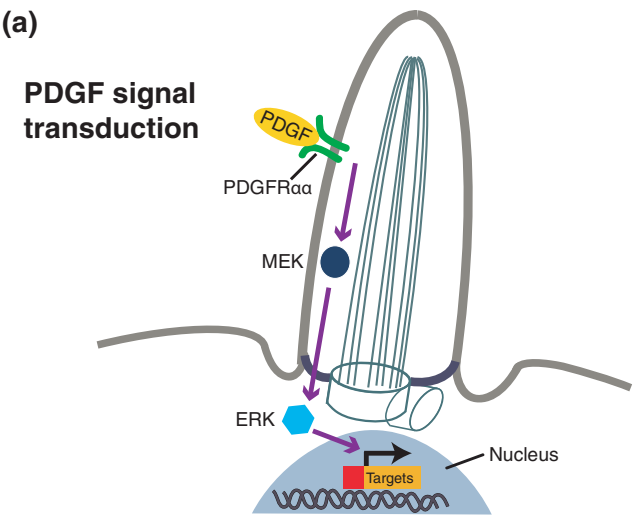

(b)

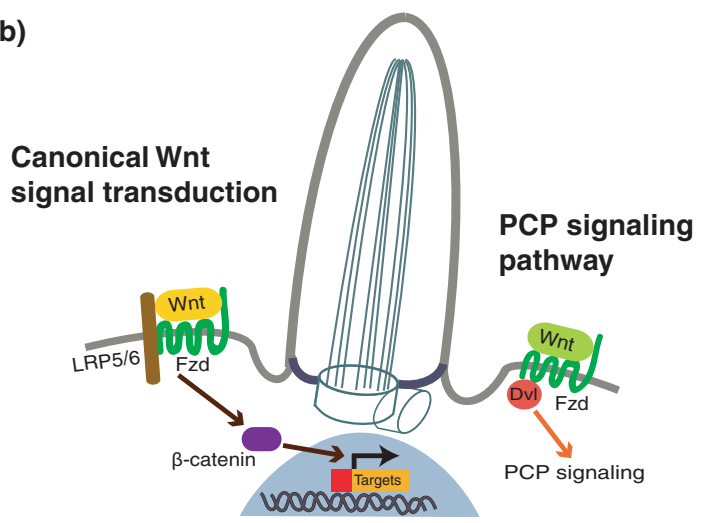

(c)

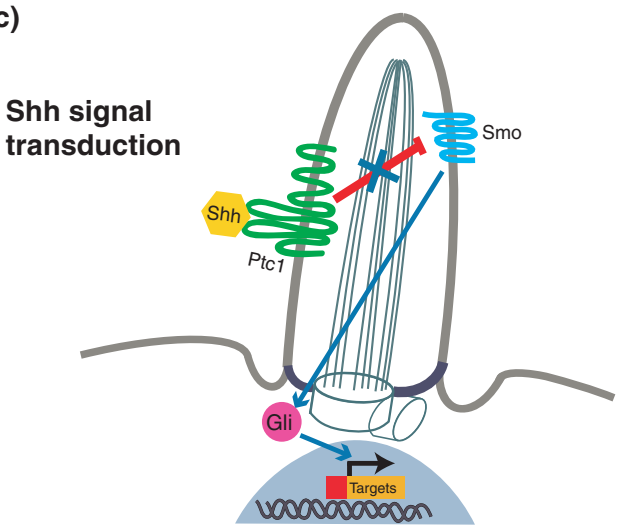

Figure 3. Various signaling pathways modulated by the primary cilium. (a) Platelet-derived growth factor (PDGF) signaling through PDGF receptor aa requires ciliary localization of the receptor to activate downstream targets mediated by the MAP kinase kinase (MEK)-extracellular signal-regulated kinase (ERK) pathway. (b) Canonical Wnt signaling through LRP5/6 and Frizzled (Fzd) is probably inhibited by the primary cilium, whereas the planar cell polarity (PCP) non-canonical pathway requires factors essential for ciliogenesis for activity, probably by mediating cellular polarity and polarized basal body localization, and is then activated by Dishevelled (Dvl) interacting with either Fzd or other PCP components. (c) Binding of Shh to patched 1 (Ptc1) activates Shh signaling by releasing inhibition of smoothened (Smo)-Gli-mediated downstream target gene transcription. genes and causative disease genes underlying ciliopathies $[18,19]$. These new technologies gave new insights into understanding pathogenesis of the disorders and ciliary biology.

\section{Proteomics}

Following the identification of many causative genes underlying specific classes of ciliopathies, it was observed that the proteins from a given class of ciliopathies tend to assemble with reproducible stoichiometry. This was first demonstrated for the complex of proteins encoded by genes mutated in BBS (called the BBSome), and has since extended to proteins from other ciliopathies, including those in the NPHP-JBTS-MKS complex [20,21]. The core of each complex is made up of the proteins identified from humans with similar disease. For example, the BBSome is constituted by tight interactions between 7 of 12 BBS proteins. The NPHP-JBTS-MKS complex contains nonoverlapping components, mostly proteins previously implicated in NPHP, JBTS and MKS, but also some unexpected proteins such as ATXN10 and TCTN2, both of which were subsequently found to be mutated in NPHP and JBTS, suggesting the likely relevance of the complex.

The BBSome and the NPHP-JBTS-MKS complex are present in the ciliary region in the absence of ciliary disease. However, the function of these complexes in ciliary biology (and ciliary disease) is still not clear, although evidence suggests that the BBSome functions as a vesicular coat that transports membrane proteins to the cilia [22]. There is mounting evidence that the NPHPJBTS-MKS complex, with an estimated molecular weight between 0.7 and $2 \mathrm{MDa}$, functions at or near the transition zone of the primary cilia and regulates ciliary entry/localization of many proteins [23]. It remains to be determined whether other multigenic ciliopathy disorders similarly display non-overlapping components and how such complexes function at or near the cilium.

Thus, it is informative to consider these as diseasespecific protein complexes, constituted by a host of nonredundant factors, each of which serves a still poorly defined function. Work in C. elegans suggests that the MKS and NPHP proteins establish basal body/transition zone membrane attachments coincident with IFTdependent axoneme extension. In this light, it is perhaps not surprising that genetic evidence obtained by crossing mutants in C. elegans demonstrates more severe synthetic phenotypes (functional interactions) only when mutations occur in two different disease modules [2]. For instance, the B9 domain proteins of the MKS module functionally interact with the NPHP module [24] but not with most other proteins in the MKS module. We can conclude that each protein complex probably forms an intricate modular network, as evidenced by specificity in the protein complexes and by functional redundancy. 


\section{Application of next-generation sequencing}

The ciliary biology field has greatly benefited from the tremendous gains in proteomics and genomics through the definition of the concept of the 'ciliome'. The ciliome consists almost completely of genes implicated in ciliary function, on the basis of a compilation of results from various studies involving human genetics, functional genetics and proteomics, and it is currently made up of more than 2,500 human orthologs. As expected, many of the genes subsequently identified as mutated in ciliopathies were already part of this compiled list, which has led to more efficient workflow by focusing on these genes. By applying next-generation sequencing (NGS) with a focus on the ciliome, new human disease genes have recently been identified in a relatively short time [25] and much larger groups of patients can be screened for existing genes, greatly aiding future genotype-phenotype correlations $[26,27]$. The phenotypic variability often shown among ciliopathy patients carrying the same combinations of mutations has suggested the presence of modifier genes and/or the involvement of tri-allelic inheritance [28-32]. NGS potentially allows sequencing of an entire human genome in a few days and outputs thousands of new variants in candidate genes. In addition, a recent study, combining a massive number of in vivo experiments [32], has tested the possibility that new deleterious variants of known causative genes may function as modifiers in ciliopathies.

NGS approaches are greatly broadening the sophistication and types of today's experiments in the ciliopathy field, as is occurring in other fields, using genome-wide approaches. By targeting human families with key ciliopathy features, and applying either homozygosity mapping or whole exome sequencing approaches to identify causative genes, several diseases that were previously not considered as ciliopathies, such as Jeune syndrome [33], acrocallosal syndrome [34] and cranioectodermal dysplasia [35-37], are now considered to be in the extended ciliopathy spectrum. Interestingly, not all genes encoding centrosomal or pericentrosomal proteins cause ciliopathies, as the recent examples involving Seckel syndrome (primordial dwarfism) have shown $[38,39]$. We thus conclude that there must be specificity of function in these centrosomal proteins, some functioning in cell cycle regulation or DNA repair and others in ciliary regulation, even if these functions are not as well delineated in non-human species [40].

\section{Application of high-throughput genomics}

Cell-based screens using high-throughput functional analysis offer an exciting opportunity to identify key regulators of cellular structure and function. Application of genetic, chemical or even genome-wide small interfering RNA libraries to ciliated cells followed by assessment of signaling or ciliary structure provides an important complementary approach to understanding ciliary-specific genetic requirements [41-44]. These cellular analyses have uncovered many important signaling mechanisms, some of which are pharmacologically tractable and may serve as a basis for the development of future therapy, in particular because the assays can be targeted to bypass specific patient-related cellular defects. For instance, we found that positive regulators of actin polymerization functioned as negative regulators of ciliogenesis [44], and vice versa, prompting us to question whether actin destabilizers might promote ciliogenesis in cellular models of disease. We found that low dose application of the actin polymerization inhibitor cytochalasin D partially rescued cilum elongation defects caused by the hypomorphic mouse mutation Ift88 [41-44]. Further genomic screening focusing on a specific cellular process, such as ciliation linked to cell cycle regulation, posttranslational modification of microtubules and regulation of ciliary transport and signaling, will lead to a greater understanding of ciliary structure/function relationships, their relevance to disease and potential treatments.

\section{Future prospects}

The broad range of clinical features observed in ciliopathies leads us to ask how defects caused in a small cellular organelle give rise to such diverse clinical features in multiple organs. Identification and functional investigation of causative genes have always been emphasized and the recent accessibility of high-throughput NGS has propelled the ciliary biology field from basic science into the biomedical realm. The main challenge of NGS, however, lies in interpreting the massive amount of resulting data. The thousands of novel mutations found in every exome must be sorted by thorough filtering of the variants to determine which one is causative. Careful selection of patients with highly similar clinical features increases the likelihood of finding many different mutations in the same genes and the ability to distinguish pathogenic from benign variants.

As ciliopathies are rare, complex, multi-symptom diseases, treatment to ameliorate the symptoms and provide better (prenatal) diagnosis will be more feasible than targeted therapies. For instance, kidney failure is the most widespread symptom among several ciliopathies. It therefore may be possible that candidate drugs used to treat kidney disease, such as polycystic kidney disease (PKD), can be used in ciliopathy patients to help alleviate kidney symptoms. With rapidly dropping costs of NGS and more sophisticated advances in bioinformatics, it may be possible to use genomics to stratify patients for optimal prescribing and/or treatment in the near future. Personalized medicine developed through comprehensive data obtained by complementary approaches may be the best hope for patients with ciliopathies. 


\section{Abbreviations}

BBS, Bardet-Biedl syndrome; CORS, cerebello-oculo-renal syndrome; IFT, intraflagella transport; JATD, Jeune asphyxiating thoracic dystrophy; JBTS, Joubert syndrome; KS, Kartagener syndrome; MKS, Meckel syndrome; NPHP, nephronophthisis; NGS, next-generation sequencing; PCP, planar cell polarity; PDGF, platelet derived growth factor; PKD, polycystic kidney disease; $P C D$, primary ciliary dyskinesia; Shh, Sonic hedgehog.

\section{Competing interests}

The authors declare that they have no competing interests.

\section{Authors' contributions}

JGG provided the overall direction and revised the manuscript. JEL drafted the initial manuscript and produced the figures and table.

\section{Acknowledgements}

JEL would like to acknowledge funding support from American Heart Association (grant number 09POST2250641). JGG is an investigator with the Howard Hughes Medical Institute. The authors would like to thank Francis Lee for giving comments on the manuscript.

Published: 26 September 2011

\section{References}

1. Hu Q, Milenkovic L, Jin H, Scott MP, Nachury MV, Spiliotis ET, Nelson WJ: A septin diffusion barrier at the base of the primary cilium maintains ciliary membrane protein distribution. Science 2010, 329:436-439.

2. Williams CL, Li C, Kida K, Inglis PN, Mohan S, Semenec L, Bialas NJ, Stupay RM, Chen N, Blacque OE, Yoder BK, Leroux MR: MKS and NPHP modules cooperate to establish basal body/transition zone membrane associations and ciliary gate function during ciliogenesis. J Cell Biol 2011, 192:1023-1041.

3. Kim JC, Badano JL, Sibold S, Esmail MA, Hill J, Hoskins BE, Leitch CC, Venner K, Ansley SJ, Ross AJ, Leroux MR, Katsanis N, Beales PL: The Bardet-Biedl protein BBS4 targets cargo to the pericentriolar region and is required for microtubule anchoring and cell cycle progression. Nat Genet 2004, 36:462-470.

4. Ansley SJ, Badano JL, Blacque OE, Hill J, Hoskins BE, Leitch CC, Kim JC, Ross AJ, Eichers ER, Teslovich TM, Mah AK, Johnsen RC, Cavender JC, Lewis RA, Leroux MR, Beales PL, Katsanis N: Basal body dysfunction is a likely cause of pleiotropic Bardet-Biedl syndrome. Nature 2003, 425:628-633.

5. Taulman PD, Haycraft CJ, Balkovetz DF, Yoder BK: Polaris, a protein involved in left-right axis patterning, localizes to basal bodies and cilia. Mol Bio/ Cell 2001, 12:589-599.

6. Afzelius BA: A human syndrome caused by immotile cilia. Science 1976, 193:317-319.

7. Omran $\mathrm{H}$, Haffner K, Volkel A, Kuehr J, Ketelsen UP, Ross UH, Konietzko N, Wienker T, Brandis M, Hildebrandt F: Homozygosity mapping of a gene locus for primary ciliary dyskinesia on chromosome $5 \mathrm{p}$ and identification of the heavy dynein chain DNAH5 as a candidate gene. Am J Respir Cell Mol Biol 2000, 23:696-702.

8. Horvath J, Fliegauf M, Olbrich H, Kispert A, King SM, Mitchison H, Zariwala MA, Knowles MR, Sudbrak R, Fekete G, Neesen J, Reinhardt R, Omran H: Identification and analysis of axonemal dynein light chain 1 in primary ciliary dyskinesia patients. Am J Respir Cell Mol Biol 2005, 33:41-47.

9. Loges NT, Olbrich H, Fenske L, Mussaffi H, Horvath J, Fliegauf M, Kuhl H, Baktai G, Peterffy E, Chodhari R, Chung EM, Rutman A, O'Callaghan C, Blau H, Tiszlavicz L, Voelkel K, Witt M, Zietkiewicz E, Neesen J, Reinhardt R, Mitchison HM, Omran H: DNAI2 mutations cause primary ciliary dyskinesia with defects in the outer dynein arm. Am J Hum Genet 2008, 83:547-558.

10. Castleman VH, Romio L, Chodhari R, Hirst RA, de Castro SC, Parker KA, YbotGonzalez P, Emes RD, Wilson SW, Wallis C, Johnson CA, Herrera RJ, Rutman A, Dixon M, Shoemark A, Bush A, Hogg C, Gardiner RM, Reish O, Greene ND, O'Callaghan C, Purton S, Chung EM, Mitchison HM: Mutations in radial spoke head protein genes RSPH9 and RSPH4A cause primary ciliary dyskinesia with central-microtubular-pair abnormalities. Am J Hum Genet 2009, 84:197-209.

11. Loges NT, Olbrich H, Becker-Heck A, Häffner K, Heer A, Reinhard C, Schmidts M, Kispert A, Zariwala MA, Leigh MW, Knowles MR, Zentgraf H, Seithe H, Nürnberg G, Nürnberg P, Reinhardt R, Omran H: Deletions and point mutations of LRRC50 cause primary ciliary dyskinesia due to dynein arm defects. Am J Hum Genet 2009, 85:883-889.
12. Caspary T, Larkins CE, Anderson KV: The graded response to Sonic Hedgehog depends on cilia architecture. Dev Cell 2007, 12:767-778.

13. Jauregui AR, Nguyen KC, Hall DH, Barr MM: The Caenorhabditis elegans nephrocystins act as global modifiers of cilium structure. J Cell Biol 2008, 180:973-988.

14. Nishimura DY, Fath M, Mullins RF, Searby C, Andrews M, Davis R, Andorf JL, Mykytyn K, Swiderski RE, Yang B, Carmi R, Stone EM, Sheffield VC: Bbs2-null mice have neurosensory deficits, a defect in social dominance, and retinopathy associated with mislocalization of rhodopsin. Proc Natl Acad SciUS A 2004, 101:16588-16593.

15. Collins FS: Positional cloning moves from perditional to traditional. Nat Genet 1995, 9:347-350.

16. Peral B, Ong AC, San Millan JL, Gamble V, Rees L, Harris PC: A stable, nonsense mutation associated with a case of infantile onset polycystic kidney disease 1 (PKD1). Hum Mol Genet 1996, 5:539-542.

17. Hildebrandt F, Otto E, Rensing C, Nothwang HG, Vollmer M, Adolphs J, Hanusch $\mathrm{H}$, Brandis M: A novel gene encoding an $\mathrm{SH} 3$ domain protein is mutated in nephronophthisis type 1. Nat Genet 1997, 17:149-153.

18. Li JB, Gerdes JM, Haycraft CJ, Fan Y, Teslovich TM, May-Simera H, Li H, Blacque OE, Li L, Leitch CC, Lewis RA, Green JS, Parfrey PS, Leroux MR, Davidson WS, Beales PL, Guay-Woodford LM, Yoder BK, Stormo GD, Katsanis N, Dutcher SK: Comparative genomics identifies a flagellar and basal body proteome that includes the BBS5 human disease gene. Cell 2004, 117:541-552.

19. Avidor-Reiss T, Maer AM, Koundakjian E, Polyanovsky A, Keil T, Subramaniam S, Zuker CS: Decoding cilia function: defining specialized genes required for compartmentalized cilia biogenesis. Cell 2004, 117:527-539.

20. Sang L, Miller JJ, Corbit KC, Giles RH, Brauer MJ, Otto EA, Baye LM, Wen X, Scales SJ, Kwong M, Huntzicker EG, Sfakianos MK, Sandoval W, Bazan JF, Kulkarni P, Garcia-Gonzalo FR, Seol AD, O'Toole JF, Held S, Reutter HM, Lane WS, Rafiq MA, Noor A, Ansar M, Devi AR, Sheffield VC, Slusarski DC, Vincent JB, Doherty DA, et al: Mapping the NPHP-JBTS-MKS protein network reveals ciliopathy disease genes and pathways. Cell 2011, 145:513-528.

21. Nachury MV, Loktev AV, Zhang Q, Westlake CJ, Peränen J, Merdes A, Slusarski DC, Scheller RH, Bazan JF, Sheffield VC, Jackson PK: A core complex of BBS proteins cooperates with the GTPase Rab8 to promote ciliary membrane biogenesis. Cell 2007, 129:1201-1213.

22. Jin H, White SR, Shida T, Schulz S, Aguiar M, Gygi SP, Bazan JF, Nachury MV: The conserved Bardet-Biedl syndrome proteins assemble a coat that traffics membrane proteins to cilia. Cell 2010, 141:1208-1219.

23. Garcia-Gonzalo FR, Corbit KC, Sirerol-Piquer MS, Ramaswami G, Otto EA, Noriega TR, Seol AD, Robinson JF, Bennett CL, Josifova DJ, García-Verdugo JM, Katsanis N, Hildebrandt F, Reiter JF: A transition zone complex regulates mammalian ciliogenesis and ciliary membrane composition. Nat Genet 2011, 43:776-784.

24. Williams CL, Winkelbauer ME, Schafer JC, Michaud EJ, Yoder BK: Functional redundancy of the B9 proteins and nephrocystins in Caenorhabditis elegans ciliogenesis. Mol Biol Cell 2008, 19:2154-2168.

25. Otto EA, Hurd TW, Airik R, Chaki M, Zhou W, Stoetzel C, Patil SB, Levy S, Ghosh AK, Murga-Zamalloa CA, van Reeuwijk J, Letteboer SJ, Sang L, Giles RH, Liu Q, Coene KL, Estrada-Cuzcano A, Collin RW, McLaughlin HM, Held S, Kasanuki JM, Ramaswami G, Conte J, Lopez I, Washburn J, Macdonald J, Hu J, Yamashita Y, Maher ER, Guay-Woodford LM, et al:: Candidate exome capture identifies mutation of SDCCAG8 as the cause of a retinal-renal ciliopathy. Nat Genet 2011, 42:840-850.

26. Otto EA, Ramaswami G, Janssen S, Chaki M, Allen SJ, Zhou W, Airik R, Hurd TW, Ghosh AK, Wolf MT, Hoppe B, Neuhaus TJ, Bockenhauer D, Milford DV, Soliman NA, Antignac C, Saunier S, Johnson CA, Hildebrandt F: Mutation analysis of 18 nephronophthisis associated ciliopathy disease genes using a DNA pooling and next generation sequencing strategy. J Med Genet 2011, 48:105-116.

27. Janssen S, Ramaswami G, Davis EE, Hurd T, Airik R, Kasanuki JM, Van Der Kraak L, Allen SJ, Beales PL, Katsanis N, Otto EA, Hildebrandt F: Mutation analysis in Bardet-Biedl syndrome by DNA pooling and massively parallel resequencing in 105 individuals. Hum Genet 2011, 129:79-90.

28. Louie CM, Caridi G, Lopes VS, Brancati F, Kispert A, Lancaster MA, Schlossman AM, Otto EA, Leitges M, Gröne HJ, Lopez I, Gudiseva HV, O’Toole JF, Vallespin E, Ayyagari R, Ayuso C, Cremers FP, den Hollander Al, Koenekoop RK, Dallapiccola B, Ghiggeri GM, Hildebrandt F, Valente EM, Williams DS, Gleeson $\mathrm{JG}: \mathrm{AHI} 1$ is required for photoreceptor outer segment development and is a modifier for retinal degeneration in nephronophthisis. Nat Genet 2010, 42:175-180. 
29. Katsanis N, Ansley SJ, Badano JL, Eichers ER, Lewis RA, Hoskins BE, Scambler PJ, Davidson WS, Beales PL, Lupski JR: Triallelic inheritance in Bardet-Biedl syndrome, a Mendelian recessive disorder. Science 2001, 293:2256-2259.

30. Bin J, Madhavan J, Ferrini W, Mok CA, Billingsley G, Heon E: BBS7 and TTC8 (BBS8) mutations play a minor role in the mutational load of Bardet-Biedl syndrome in a multiethnic population. Hum Mutat 2009, 30:E737-746.

31. Khanna H, Davis EE, Murga-Zamalloa CA, Estrada-Cuzcano A, Lopez I, den Hollander Al, Zonneveld MN, Othman MI, Waseem N, Chakarova CF, Maubaret C, Diaz-Font A, MacDonald I, Muzny DM, Wheeler DA, Morgan M, Lewis LR, Logan CV, Tan PL, Beer MA, Inglehearn CF, Lewis RA, Jacobson SG, Bergmann C, Beales PL, Attié-Bitach T, Johnson CA, Otto EA, Bhattacharya SS, Hildebrandt F, et al:: A common allele in RPGRIP1L is a modifier of retinal degeneration in ciliopathies. Nat Genet 2009, 41:739-745.

32. Davis EE, Zhang Q, Liu Q, Diplas BH, Davey LM, Hartley J, Stoetzel C, Szymanska K, Ramaswami G, Logan CV, Muzny DM, Young AC, Wheeler DA, Cruz P, Morgan M, Lewis LR, Cherukuri P, Maskeri B, Hansen NF, Mullikin JC, Blakesley RW, Bouffard GG, Gyapay G, Rieger S, Tönshoff B, Kern I, Soliman NA, Neuhaus TJ, Swoboda KJ, Kayserili H, et al:: TTC21B contributes both causal and modifying alleles across the ciliopathy spectrum. Nat Genet 2011, 43:189-196.

33. Beales PL, Bland E, Tobin JL, Bacchelli C, Tuysuz B, Hill J, Rix S, Pearson CG, Kai M, Hartley J, Johnson C, Irving M, Elcioglu N, Winey M, Tada M, Scambler PJ: IFT80, which encodes a conserved intraflagellar transport protein, is mutated in Jeune asphyxiating thoracic dystrophy. Nat Genet 2007, 39:727-729.

34. Putoux A, Thomas S, Coene KL, Davis EE, Alanay Y, Ogur G, Uz E, Buzas D, Gomes C, Patrier S, Bennett CL, Elkhartoufi N, Frison MH, Rigonnot L, Joyé N, Pruvost S, Utine GE, Boduroglu K, Nitschke P, Fertitta L, Thauvin-Robinet C, Munnich A, Cormier-Daire V, Hennekam R, Colin E, Akarsu NA, Bole-Feysot C, Cagnard N, Schmitt A, Goudin N, et al:: KIF7 mutations cause fetal hydrolethalus and acrocallosal syndromes. Nat Genet 2011, 43:601-606.

35. Walczak-Sztulpa J, Eggenschwiler J, Osborn D, Brown DA, Emma F, Klingenberg C, Hennekam RC, Torre G, Garshasbi M, Tzschach A, Szczepanska M, Krawczynski M, Zachwieja J, Zwolinska D, Beales PL, Ropers HH, LatosBielenska A, Kuss AW: Cranioectodermal dysplasia, Sensenbrenner syndrome, is a ciliopathy caused by mutations in the IFT122 gene. Am J Hum Genet 2010, 86:949-956.

36. Gilissen C, Arts HH, Hoischen A, Spruijt L, Mans DA, Arts P, van Lier B, Steehouwer M, van Reeuwijk J, Kant SG, Roepman R, Knoers NV, Veltman JA, Brunner HG: Exome sequencing identifies WDR35 variants involved in Sensenbrenner syndrome. Am J Hum Genet 2010, 87:418-423.
37. Arts HH, Bongers EM, Mans DA, van Beersum SE, Oud MM, Bolat E, Spruijt L, Cornelissen EA, Schuurs-Hoeijmakers JH, de Leeuw N, Cormier-Daire V, Brunner HG, Knoers NV, Roepman R: C14ORF179 encoding IFT43 is mutated in Sensenbrenner syndrome. J Med Genet 2011, 48:390-395.

38. Kalay E, Yigit G, Aslan Y, Brown KE, Pohl E, Bicknell LS, Kayserili H, Li Y, Tüysüz B, Nürnberg G, Kiess W, Koegl M, Baessmann I, Buruk K, Toraman B, Kayipmaz S, Kul S, Ikbal M, Turner DJ, Taylor MS, Aerts J, Scott C, Milstein K, Dollfus H, Wieczorek D, Brunner HG, Hurles M, Jackson AP, Rauch A, Nürnberg P, et al: CEP152 is a genome maintenance protein disrupted in Seckel syndrome. Nat Genet 2011, 43:23-26.

39. Rauch A, Thiel CT, Schindler D, Wick U, Crow YJ, Ekici AB, van Essen AJ, Goecke TO, Al-Gazali L, Chrzanowska KH, Zweier C, Brunner HG, Becker K, Curry CJ, Dallapiccola B, Devriendt K, Dörfler A, Kinning E, Megarbane A, Meinecke P, Semple RK, Spranger S, Toutain A, Trembath RC, Voss E, Wilson L, Hennekam $R$, de Zegher F, Dörr HG, Reis A: Mutations in the pericentrin (PCNT) gene cause primordial dwarfism. Science 2008, 319:816-819.

40. Miyoshi K, Kasahara K, Miyazaki I, Shimizu S, Taniguchi M, Matsuzaki S, Tohyama M, Asanuma M: Pericentrin, a centrosomal protein related to microcephalic primordial dwarfism, is required for olfactory cilia assembly in mice. FASEB J 2009, 23:3289-3297.

41. Engel BD, Ishikawa H, Feldman JL, Wilson CW, Chuang PT, Snedecor J, Williams J, Sun Z, Marshall WF: A cell-based screen for inhibitors of flagelladriven motility in Chlamydomonas reveals a novel modulator of ciliary length and retrograde actin flow. Cytoskeleton (Hoboken) 2011, 68:188-203.

42. Evangelista M, Lim TY, Lee J, Parker L, Ashique A, Peterson AS, Ye W, Davis DP, de Sauvage FJ: Kinome siRNA screen identifies regulators of ciliogenesis and hedgehog signal transduction. Sci Signal 2008, 1:ra7

43. Lai CK, Gupta N, Wen X, Rangell L, Chih B, Peterson AS, Bazan JF, Li L, Scales SJ: Functional characterization of putative cilia genes by high-content analysis. Mol Biol Cell 2011, 22:1104-1119.

44. Kim J, Lee JE, Heynen-Genel S, Suyama E, Ono K, Lee K, Ideker T, Aza-Blanc P, Gleeson JG: Functional genomic screen for modulators of ciliogenesis and cilium length. Nature 2010, 464:1048-1051

doi:10.1186/gm275

Cite this article as: Lee JE, Gleeson JG: A systems-biology approach to understanding the ciliopathy disorders. Genome Medicine 2011, 3:59. 